\title{
BLACK SEA SECURITY AND ASYMMETRIC MILITARY THREATS IN THE 21ST CENTURY: NEW TRENDS AND NEW CHALLENGES
}

\author{
Professor Vakhtang Maisaia Ph.D. ${ }^{321}$
}

\begin{abstract}
The Black Sea region is increasingly becoming a priority on the international agenda. In fact, a regional approach is emerging as actors understand that common problems need to be addressed jointly. Nevertheless, cooperation efforts are hampered by a number of factors, such as uneven economic and political development within and among countries, nationalist forces, and longstanding animosities between regional players. In this context, it is imperative to foster sound policies aimed at strengthening dialogue and cooperation so as to contain and ultimately resolve conflicts with peaceful means. However, there is little policy-oriented research on the challenges and opportunities for cooperation in the Black Sea region. The purpose of this paper is to assess the impact of terrorism and its dangers towards the Black Sea region. The work also describes the significance of international terrorism and its general definitions. Besides, the result and findings are based on theoretical studies and assumptions and the result of the analysis of the "Case Study" of the Black Sea region. Case study examines how the Black Sea region influences the spread of terrorism and what threats it poses for this region. Furthermore, the aspects of what makes the region important on international arena are analyzed and the existent and potential security issues are examined, as well as strategic importance of the region for the EU and NATO is analyzed even from academic framework"Securitization" theory ${ }^{322}$. The theory is based on security studies conceptual background and the background spectrum includes: the Copenhagen School and Critical security studies as the type $e^{323}$.
\end{abstract}

Keywords: Black Sea region, Copenhagen School, Critical security studies, Securitization, NATO, EU, Georgia's national security.

The Black Sea Region is one of the main factors in the make-up of security and stability in Europe and Asia. In addition to the numerous other issues in the region, ethnic conflicts, ongoing state-building processes, the presence of vast natural resources, and strategic transport and energy corridors mean that the region is an extremely important and sensitive area.

\footnotetext{
${ }^{321}$ Dr. Vakhtang Maisaia Ph.D. is Professor at Caucasus International University (Georgia), Warsaw University (Republic of Poland) and is member of the Political Science Association (Republic of Poland). Professor Maisaia previously served as Georgia's President's State Advisor on Caucasus Regional Security Affairs (1997-1999).

${ }^{322}$ Buzan B., Waever O. and De Wilde J., Security, A New Framework For Analysis, Lynne Reinner Publishers, London, 1998, pp.17-24.

${ }^{323}$ Robert Ondrejcsak, Introduction to Security Studies, Centre for European and North Atlantic Affairs (CENAA), Bratislava, 2014, p.25.
} 
In geographical terms it is difficult to specify the boundaries of the Black Sea Region, since there are numerous regional and sub-regional structures. In the post-Cold War period there has been a large measure of openness to several neighboring areas, such as the Mediterranean, the Balkans, and the Caspian region. This kind of openness makes it difficult to define both the nature of the region and its borders. It is reflected in terms such as "Black-Caspian Seas Region" and "Black-Mediterranean Seas Region". Some analysts have even argued that the Black Sea Region is simply an intellectual invention. In order to avoid confusion, this policy report is based on the definition adopted by the Organization of the Black Sea Economic Cooperation (BSEC). The Black Sea Region is one of the main factors in the make-up of security and stability in Europe and Asia. In addition to the numerous other issues in the region, ethnic conflicts, ongoing state-building processes, the presence of vast natural resources, and strategic transport and energy corridors mean that the region is an extremely important and sensitive area.

In geographical terms it is difficult to specify the boundaries of the Black Sea Region, since there are numerous regional and sub-regional structures. In the post-Cold War period there has been a large measure of openness to several neighboring areas, such as the Mediterranean, the Balkans, and the Caspian region. This kind of openness makes it difficult to define both the nature of the region and its borders. It is reflected in terms such as "Black-Caspian Seas Region" and "Black-Mediterranean Seas Region". Some analysts have even argued that the Black Sea Region is simply an intellectual invention. In order to avoid confusion, this policy report is based on the definition adopted by the Organization of the Black Sea Economic Cooperation (BSEC).

At the end of the Cold War, the states around the Black Sea regained their freedom and escaped from a bipolar conceptual straitjacket. This historical event not only marked the start of a move towards independence, democracy and market economy, but also unleashed hitherto suppressed ethnic, national and territorial conflicts, and even terrorism. From the early 1990s onwards, the region witnessed armed conflicts and an increase in political tension. Political and territorial disagreements such as border disputes and clashes between both peoples and states are the main reason why the prospects for regional security cooperation are rather bleak. The Black Sea basin was of secondary importance for the EuroAtlantic community during the 1990s as it focused on stabilizing and integrating central and eastern European countries from the Baltic to the Black Sea. However, in the 21 st century the changing global and regional balances created new political and security dilemmas for the Black Sea Region. The global and regional powers increasingly supported competing political and security agendas which, although they occasionally contradicted each other, were clearly interlinked.

After September 11, 2001, the US increased its involvement in the region, for example with new programs in Georgia and Ukraine. This went hand in hand 
with the European Union (EU) and North Atlantic Treaty Organization (NATO) enlargement processes and global political developments. The differing approaches to the creation of security and stability in the region led to tension and rivalry between the regional actors.

In the post-Cold War period, the Black Sea Region failed to develop a cooperative security vision or structure in which the regional actors would have been the principal stakeholders. The Russian-Georgian War in August 2008 showed quite clearly that the initiatives designed to pacify the region had not produced a security system capable of preventing or containing internal and interstate conflicts. One lesson that can be learned from the August 2008 crisis is that the interplay of regional and global forces will continue to dominate future political and military issues in the region. It remains to be seen whether the war in August 2008 will lead to a new cooperative security environment in the Black Sea Region. Finally, all kinds of security issues ranging from energy security to environmental degradation and from terrorism to illegal trafficking in arms, human beings and drugs continue to be unresolved as a result of international rivalry.

Another important issue is energy security. The need to achieve energy supply diversity on the one hand and the risks associated with energy dependency on Russia on the other show the importance of gas and oil from other sources being piped to the European markets through the region. The energy dispute between Russia and Ukraine in late 2008 and early 2009 clearly illustrated the importance of energy security for the region and the EU. In addition to exploration, production and transport-related problems, oil and natural gas have become one of the main security issues in the Black Sea Region, which as the principal energy transit route, is also a testing ground for the interaction between producer, consumer and transit countries. This means that the region is not only a potential hub. There are also numerous rivalries.

Finally, a number of problems associated with soft security issues which range from environmental concerns to the potential for social unrest and economic collapse need to be analyzed, especially if there is a likelihood that they will disrupt political stability and security in the region. Potential destabilizing threats such as the global financial crisis also need to be kept under review, as does the impact of the crisis on the countries in the region or on the redefinition of the roles of the regional powers, and the opportunities arising from a redefinition of the global economic environment.

By and large, the Black Sea region is also increasing of geo-economic importance especially with regard to developing energy security provisions in aegis of the European Union via the import and providing transit opportunities from the Caspian Basin, Middle East and Central Asia and becoming some kind of energy gateway that is so important for providing and fostering security and stability implications in the Pan-European Area. It is interesting to underpin that 
energy security in Wider Black Sea region is defined by the concrete scientific and academic analytical school approaches reflected in international relations, like interdependence theory ${ }^{324}$.

\section{GEOPOLITICAL CLASSIFICATION OF THE BLACK SEA REGION - WIDER BLACK SEA IMPLICATION FOR THE WORLD POLITICS}

In above mentioned passage was depicted geographical implications for the Black Sea region but due to the geopolitical transmission and transformation after bipolar system demolition in contemporary international relations the regional security is being increased steadily. There are several indications why the region has become so important and unique not only in Cold War period but mostly afterwards. Here is to mention first of all very unique geopolitical implication of the region. The region is applicable with primary accessibility to "Three Oceans" line (Nord, Atlantic and Indian Oceans - see Map\#1) via gateways Black Sea Basin, Persian Gulf and Central Eurasia. Moreover, concrete geopolitical determinants of importance of the region is considered with three main criteria having pure geopolitical meaning.

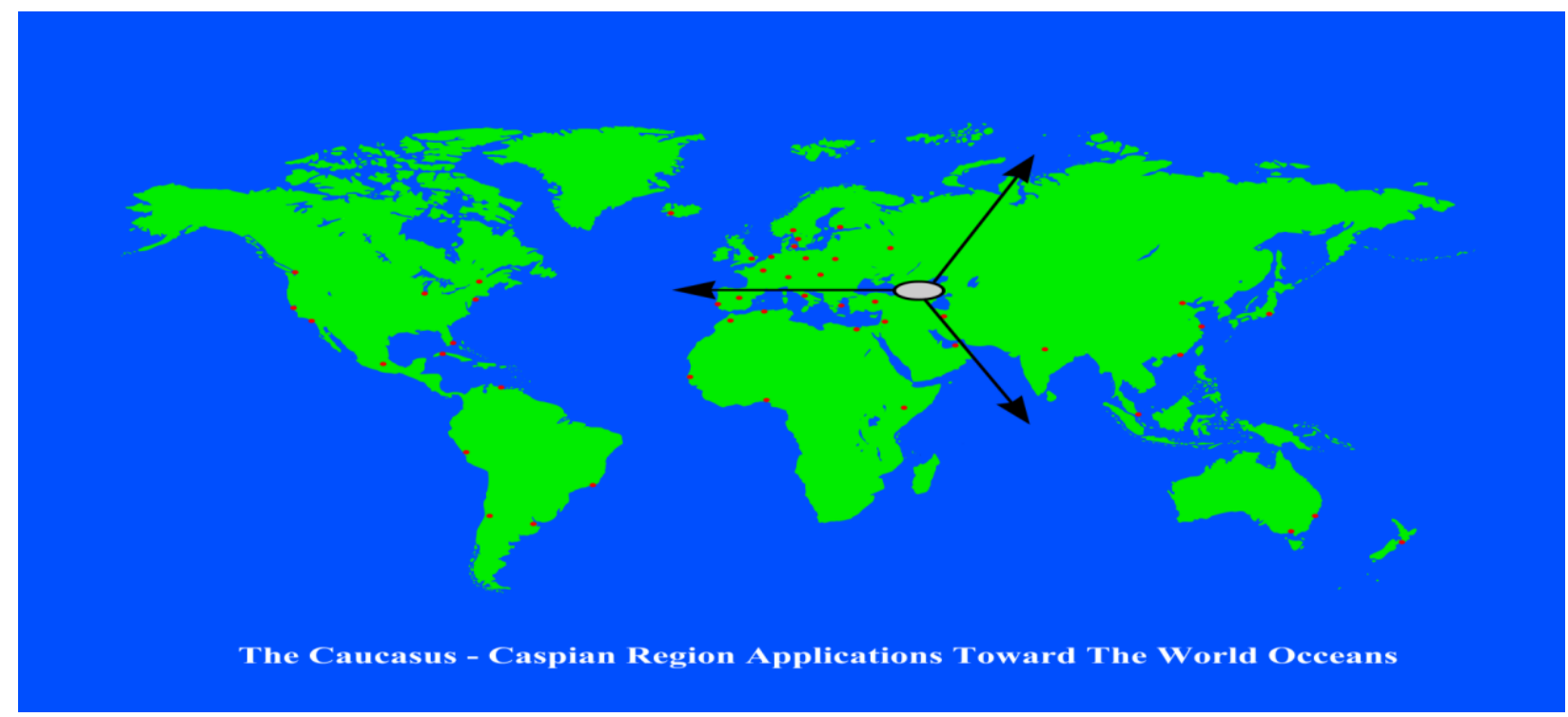

Map\#1: The Black Sea Region applicability toward “Three Oceans” line

These unique geopolitical indications are sought to be as following:

Combination of three concepts: Talasokratia+Telurokratia+Montekratia "Eurasian Balkan" acronym for spurring new asymmetric challenges

Key international energy gateway providing unlimited delivery of energy resources to international markets

\footnotetext{
${ }^{324}$ Iulian Chifu, Andriana Sauliuc, Bogdan Nedea, Energy Security Strategies in the Wider Black Sea Region, Editura Curtea Veche, Bucharest, 2010, p.9.
} 
Nevertheless, the geopolitical implication is only so-called "macro" level of analysis and is fitted to Pan-regional classification and global political relevance of the region. In order to provide so-called "micro" level of analysis and importance of the region in aegis of the regional and local implications there are some approaches to make classification of the Black Sea region. The classification is based on classical geopolitical identification similar that of British geopolitical school founder Professor Helford Mackinder's "Heartland Theory". According to his theory Mackinder defined the global geopolitical system into three main territorial areas: "Pivot Area" (or another way "Heartland"), "Inner or Marginal Crescent" and "Lands of the Outer or Insular Crescent"325. Even Mackinder endorsed simplistic dictum upon based on which he identified then world order:

"Who rules East Europe commands the Heartland:

Who rules the Heartland commands the World-Island:

Who rules the World-Island commands the World ${ }^{326 ", .}$

In this respect, based on the classical geopolitical methodology is possible to define geopolitical identification of the Black Sea region. Having considered the above-mentioned passage is necessary to figure out the following possible configuration. The configuration is clearly identified regional geopolitical architecture in three concrete circles, similar of British classical geopolitical school approach:

Black Sea Basin - "Inner Core" Ring - namely six littoral states of the Black Sea itself (Bulgaria, Turkey, Ukraine, Georgia, Russian Federation);

Black Sea Region - "Outer Core Ring" - the land and seascape from the Balkans to the Caucasus and fro Ukrainian and Russian steppe to Anatolia;

Wider Black Sea Region (Area) - "Close Outer" Ring - the territory encompasses the following geopolitical spaces MENA, Caspian Basin, South and Eastern Europe.

Considering the geopolitical classification is important to clarify the dispositional characteristics of the regional "circles". The scheme means demonstrating true geopolitical content each of the "circles" - for instance, Black Sea Basin associated with "Talassokratia ${ }^{327 "}$ geopolitics, Black Sea Region associated with "Montecracy 328 " geopolitics and Wider Black Sea Area (Region) - associated with "Telurokratia"329" geopolitics.

Roughly this is geopolitical modality of the Black Sea region and follow up the British geopolitical school founder Mackinder's dictum is very possible to

\footnotetext{
${ }^{325}$ Gearoid O Tuathail, Critical Geopolitics: The Politics of Writing Global Space, Routledge Publishing House, London, 1996, p.33.

${ }^{326}$ Robert D. Kaplan, The Revenge of Geography, Random House Trade Paperbacks, New York, 2013, p.74

${ }^{327}$ Talassokratia - geopolitical means sea power domain in politics.

${ }^{328}$ Montecracy - geopolitical jargon implies influence of mountainous geographic terrain on foreign political and military strategic decisions.

${ }^{329}$ Telurokratia - geopolitical jargon means land power domain in politics.
} 
create the same version for the regional dimension and if the dictum exists, the one is to be as follow:

"Who rules Black Sea Basin commands the Eurasia (Post-Soviet Space):

Who rules Black Sea Region commands the Pan-Europe:

Who rules Wider Black Sea Region commands the World Politics".

This interesting approach is really containing historical provisions detrimental influenced the regional geopolitics. The most important and critical challenge is the fact that there are a large number of actors and clashing interests within the Black Sea Region. In security terms the region suffers from several historical legacies. The Black Sea Region used to be treated as a 'passive area' and analyzed as the periphery of more significant geographical units.

Thus, the Black Sea basin has been variously described as the backyard of the Ottoman and Russian Empires, as an extension of Soviet zone of influence, as the frontier of Europe, and, finally, as the extension of the Mediterranean world. Moreover, the existence of several distinct sub-regions within the Black Sea Region, i.e. the Caucasus, the Balkans and to a certain extent the Mediterranean, Eastern Europe and the Middle East, is another factor that destabilizes the area. Time and again sub-regional identities have prevented the emergence of a Black Sea identity, created instability, and impeded the establishment of a comprehensive regional security framework. There are both regional and nonregional actors in the Black Sea Region, and three principal actors exert varying degrees of influence on the available security policy options (reflection of the passage is below).

At present time, The Black Sea region is becoming very important one to world markets because it has large oil and gas reserves that are only now bargaining to be fully developed (taking in consideration of energy resources of Azerbaijan, the Ukraine, Romania, Russia, transit potency of Georgia, Bulgaria, Turkey and very closed disposition toward the Caspian Basin). Developing these resources has resulted in competition both between companies to get the contracts to develop this potential, and between nations to determine the final export routes. According to experts of the RAND Corporation the Caspian oil potential today is $2 \%$ of the world's total (Venezuela has one-fourth of such reserves; Iraq, oneseventh; and Saudi Arabia, one-seventeenth).

Therefore, the Caspian Sea region's oil and gas potential and the Black Sea region's transition ability have attracted much attention since the breakup of the Soviet Union. Due to the unique geopolitical location, the Black Sea region interlines four very important areas: the Middle East, the Central Europe, the Central Asia and Western Europe thus more raising political status of the region for the international society. The nations in the Black Sea region and nearby "gateways" (term used by the American scientist Saul B. Cohen ${ }^{330}$ and in this context means geographical one for key passages of the Black Sea for shipping of

\footnotetext{
${ }^{330}$ David Minix, Samuel Hawley “Global Politics”, Wadsworth Publishing Company, New York, 1998, pp.50-51.
} 
oil and gas)-the Caucasus - Azerbaijan, Georgia, Ukraine, Turkey, Romania, Russia, Bulgaria are already major energy producers and exporters, and production will increase with additional investment, technology, and the development of new export outlets.

The Caspian Sea is 700 miles long and contains 6 separate hydrocarbon basins. However, the Caspian Sea strategic reserves importance is difficult to consider by exclusion of the South-East Europe and the South Caucasus regions. The South Caucasus' strategic importance cannot be overestimated: it is a link between the North and the South (Russia and the Persian Gulf), it is a source of oil and gas for the European and Pacific markets ${ }^{331}$. Besides one should perceive the regional geopolitical perspective. The Caucasus has an important geopolitical role to play as a link between the North and the South (Central Eurasia, which is Russia, and the Middle East) and the West and the East (Western Europe-the Balkans-the Caucasus-Central Asia-Southeast Asia-the Far East). The true mechanism of managing the "resources" distribution requires stable and cohesive political stability and basement. It drives all nations to engage into a new relationship mechanism and by joint effort to build democracy, free-minded society and rigid statehood. Otherwise, to say the broader Black Sea-CaspianCentral Asian dimension, bringing in all countries of the Black Sea and Caspian Sea, would be based on the existing mechanism of the Organization for the Black Sea Economic Cooperation (BSEC) of which the countries of the Caucasus and the South-East Europe are members. The BSEC organization itself would be upgraded in operationally, with full membership now appropriate for the EU in view of the status of Bulgaria, Romania and Turkey as accession candidates, and possible association links with the South Caucasus as well as their membership in the NATO. The institutionalization might be laying foundation for further development of the Black Sea reserves exploitation to benefit all participated nations and societies. This is a real chance for the regionalization success achievement and integrative negotiation ends.

\section{ASYMMETRIC THREATS IN A BLACK SEA REGION - MILITARY STRATEGICALLY AND OPERATIONAL LEVELS}

Demonstrate the nature of asymmetric warfare the example of the Black Sea region reflects well what kind of forces Actors have. In a broad sense, we can see it as a match of interests and there is also self-interest in the game. The existence of asymmetric threats in the Black Sea region give rise to this region is a strategically important corridor for trade, transport and energy routes between Asia and Europe and has a very specific role for Europe, USA, Russia, Turkey and other countries. The Black Sea has coastlines in six countries, including the EU member states Bulgaria and Romania and NATO member countries Romania,

\footnotetext{
${ }^{331}$ Vakhtang Maisaia "The Caucasus-Caspian Regional and Energy Security Agendas - Past, Contemporary and Future Geopolitics: View from Georgia”, second edition, IREX, Brussels, 2007, pp.15-17.
} 
Bulgaria and Turkey. Until the 20th century there was the Black Sea mare nostrum for Empires (Byzantine, Ottomans, and Russia). The Soviet had its own interests. During the Cold War Black Sea was divided with blocks and after all, Turkey wanted to build a south-east European geostrategic area. The Black Sea can become the main transport and energy transit corridor and also the route for the transfer of Central Asian resources to Europe. This dimension comes in correlation with 21 st Century challenge ${ }^{332}$. Current challenge is energy and energy routes, e.g. Europe need the Black Sea to diversify its transit routes: to the Caspian Sea to Central Asia, to Iran and maybe at some point to Iraq. Ukraine is working closely with Azerbaijan and Georgia to develop such routes. The Black Sea region is geopolitical place for three large dimensions: US, EU, Russia.

The term "asymmetry", "asymmetrical threat" or "asymmetrical warfare" is used very often, nowadays the term "asymmetric warfare" is understood as employing terrorist methods.

In Modern Warfare Klaus-Peter Lehmann defines asymmetry as a lack of symmetry, i.e. the existence of an imbalance. This imbalance can be expressed in a number of ways ${ }^{333}$. He identifies five basic asymmetries:

- the classic imbalance of forces,

- the different determination or motivation,

- the different legitimation or statehood (i.e. non-state Opponents are usually not on a legitimate, rule of law Base),

- a discrepancy in the methods used,

- the different quality of the resources.

In this sense, a conflict is always asymmetrical when there are significant differences in terms of the forces, means and methods used, but also in terms of the motivation and morality of the opponents. ${ }^{334}$ "The terms Asymmetric Warfare and Asymmetric Threats are used for the type of security threat that is directed against political, strategic, military and economic structures in a form that does not correspond to the typical conventional threat scenarios. Asymmetry always exists when one of the conflicting parties behaves unexpectedly differently, for example through a new form of tactic, with an unexpected use or a different use of existing weapons, or through attacks against, other targets"."335 Asymmetries of strength arise from the fact that one side gains a lead over its opponents through permanent innovations in military organization and weapons technology, which

\footnotetext{
${ }^{332}$ Vakhtang Maisaia and Magdana Beselia, Asymmetrical Warfare Strategy and Its Implications to the Black Sea Regional Security in $21^{\text {st }}$ Century: Non-State Aggressive Actors and Terrorism, in "Ante Portas - Security Studies"\#2(15), Poland, 2020, p.74-75.

${ }^{333}$ Ibidem, p.75.

${ }^{334}$ Klaus-Peter Lohmann, Zur Entwicklung der modernen Kriegführung. Grundlegende Asymmetrien und eine mögliche Strategie, In: Josef Schröfl, Thomas Pankratz, (Hg.), Asymmetrische Kriegsführung - ein neues Phänomen der Internationalen Politik? Nomos-Verlagsgesellschaft, Baden-Baden 2004, S. 57-62.

${ }^{335}$ Friedrich Korkisch, Die amerikanische Sicht: Asymmetric Warfare. In: Josef Schröfl, Thomas Pankratz, (Hg.). Asymmetrische Kriegsführung - ein neues Phänomen der Internationalen Politik? Nomos-Verlagsgesellschaft, Baden-Baden 2004, S. 145.
} 
can no longer be made up within a foreseeable period of time. Tried doing it the superior side of shooting up new spheres and new spaces for the purposes of warfare, into which the other side cannot follow to technological inferiority ${ }^{336}$. These threats are deriving from the conceptual and practical activities performed by the Armed Forces units of the Russian Federation.

This is good case to define what it means jargon "Asymmetric Threat". Hence, there is one of the definitions, upon to which, "Asymmetric Threat irregular threat of using power as source of the threat to define purpose of attack as well as means and capabilities causing serious harm to a state» ${ }^{337}$. Asymmetry of strength is opposed to the asymmetry from weakness, where the loser tries to evade the superior side with the help of creative strategies and tactic. A classic form of strategic asymmetry out of weakness is the partisan war, the aim of which is not to reveal oneself, to evade open combat, and to act from behind the scenes, attack like a raid and then go into hiding again. The asymmetry based on the idea that the fighters tend to be unrecognizable. The aim is to extend the war over space and time, and to wear down the superior enemy. Partisan war was considered the prevailing asymmetric Strategy to offer resistance to a technologically and organizationally superior opponent, very often the central goal of the partisan struggle was to become a state actor and thus to achieve rebalancing. The most important difference between partisan struggle and terrorism is that partisan struggle is basically of a defensive nature, while the terrorism strategy also offers offensive options for the defeated opponent. ${ }^{338}$

Today there is no longer any doubt that the line between war and peace is becoming increasingly mixed and it is being purposely obscured for strategic reasons - states are destabilized from inside, for example by inciting minorities, perhaps that Indicate - that, the hybrid warfare has begun to achieve political goals. The hybrid warfare indicates Flexible mixed form of the open and covertly applied, regular and irregular, symmetrical and asymmetrical, military and nonmilitary means of conflict with the purpose of blurring the threshold between the binary states of war and peace, particularly under international law.

In hybrid wars are on three different fronts action:

- on conventional battlefields;

- with the public and the population of the attacked country;

- among the home population and the international public.

Hybrid wars are therefore carried out by both state and non-state actors. These multimodal activities are generally operationally and tactically geared towards achieving synergy effects in the physical and psychological dimensions

\footnotetext{
${ }^{336}$ Bernhard Richter, Irreguläre Kriegsführung am Beispiel des Libanonkrieges im Sommer 2006, ARMIS ET LITTERIS 18. Wien, 2006, p 171.

337 В.Н. Конышев, А.А. Сергунин «Современная военная стратегия», учебное пособие, издательство «Аспект Пресс», Москва, 2014, стр.15.

${ }^{338}$ Herfried Münkler: Der Wandel des Krieges - Von der Symmetrie zur Asymmetrie. Verlag Velbrück Wissenschaft, Weilerswist 2006, S. 148.
} 
of the conflict ${ }^{339}$. This means that hybrid warfare can be achieved through the use of both conventional and irregular combat modes, not characterized only in the military but also in the economic sense and by the intensive use of the media to wage an information war.

Becomes Hybrid warfare the "dark side" of globalization and new technologies? - That is the question, but the fact is, that Globalization and new technologies (Cyberspace) act as a catalyst for hybrid methods of warfare. In the 21 st century, the decisive characteristic for security policy is asymmetrical threats or warfare they arise in many forms. Some of these forms of asymmetrical threats or warfare can be conventional we speak of robbery, ambush, surprise, deception, subversion, the appearance of irregular forces, hacker attacks from cyberspace against the ICT infrastructure, etc. ${ }^{340}$ The prospective get demonstrate, if terrorism will become the central threat in the 21 st century, but at the instant after September 9/11 2001, terrorism has moved to the center of threat perception as almost the most important asymmetrical threat or form of asymmetrical warfare, and it can be assumed that this perception will continue.

According to some academic sources, there are many different definitions of the doctrine, but one of them: Asymmetric Warfare - is war between belligerents whose relative military power differs significantly from or whose strategy or tactics differ significantly ${ }^{341}$. This is contrast to symmetric warfare, where two powers have similar military power and resources and rely on strategy that are similar overall, differing only in details and execution ${ }^{342}$.

A popularity of new war theory in strategic studies, labeled as "hybrid war" is being determined by the importance of globalization effect on global security and contemporary international relations system. Here is to be considered hybrid war phenomenon. Having considered several assumptions, it is possible to identify definition of the hybrid war - hybrid war is primarily based on the ability to target distant objects and processes through non-traditional military means, particularly those critical to state and military functions ${ }^{343}$.

It is important to admit that hybrid war is waging mainly between state and non-state opponents (including terrorists, like "Taliban", DAESH, etc.) that is

\footnotetext{
${ }^{339}$ Hoffmann, Frank G., Conflict in the 21st Century: The Rise of Hybrid Wars, (Potomac Institute for Policy Studies), Arlington 2007.

${ }^{340}$ Friedrich Korkisch, Die amerikanische Sicht: Asymmetric Warfare. In: Josef Schröfl, Thomas Pankratz,

(Hg.): Asymmetrische Kriegsführung - ein neues Phänomen der Internationalen Politik?, NomosVerlagsgesellschaft, Baden-Baden 2004, S. 147.

${ }^{341}$ Peter Bator, International Conflict Management - Crisis, War and Peace in "Introduction to Security Studies", Centre for European and North Atlantic Affairs (CENAA), Bratislava, Slovakia, 2014, p.42.

342 Arrenguin-Toft I., How to Weak Win Wars: A Theory of Asymmetric Conflict, in "International Security", Vol.26, 2001, c. 1, s. 93-128.

${ }^{343}$ Yuriy Danyk, Tamara Maliarchuk and Chad Briggs, Hybrid War: High-tech, Information and Cyber Conflicts, in "Connections" The Quarterly Journal, Partnership for Peace Consortium of Defense Academies and Security Studies Institutes, Vol.16, no.2, Germany, Spring 2017, p.6.
} 
fully corresponded to realms of fourth war generation ${ }^{344}$. Herewith is being interested to present the author's view on identification of hybrid war. Hybrid War Concept - method of waging combat operations by coercive power elements with non-military means and with insurgency tactical components pursuing goal of destroying and demoralizing excessive enemy forces and subverting their will for further resistance. Hence, hybrid war is indispensable component of the Fourth War generation concept aiming at destructed enemies political will and culture for continuous further resistance. The tendency of threats and challenges getting evolved into asymmetric warfare doctrine are being developed at regional levels and these ones are disseminating in aegis of the Black Sea Regional Security System.

\section{CONCLUSION}

The Black Sea regional geopolitics is still actual and very relevant from theoretical framework of international relations and security studies and from realpolitik perspective. However, this achievement would be made fragile, as the Black Sea region has become one of the world's most tragic humanitarian, political and economic disaster zones. The region enters the 21-st century still drinking the deadly cocktail of $19^{\text {th }}$ century nationalism and great power rivalry. The insecurity of the region also blocks the development of the wider Black SeaCaspian-Central Asian economic axis. New dangerous challenges - terrorism and low intensity conflicts can subvert the Security System of the region. These might be considering as "external" but little aware political constraints that curb and grave all prosperous dreams of the nations. Hence, the regional system in the Black Sea area is very dual fold and prone toward instability but with opportunity for enhancing security provisions in nearest future. Moreover, the Black Sea regional security and geopolitics are to be reviewed and scrutinized in several modalities in aegis of the Securitization theory, like military and economic sectors. In addition to that the Black Sea Region has to contend with numerous threats of a conventional and non-conventional kind. These hard and soft security problems make the region volatile, insecure and unstable. That is why the region is very vital for inter-governmental organizations, dealing with military security (NATO case) and local actors in case of Georgia's national security.

\section{BIBLIOGRAPHY}

- Arrenguin-Toft I. "How to Weak Win Wars: A Theory of Asymmetric Conflict" in "International Security", Vol.26, the UK, 2001.

\footnotetext{
${ }^{344}$ William S. Land "Understanding Fourth Generation War" in magazine "Military Review”, September-October, 2004.
} 
- Bator P., "International Conflict Management - Crisis, War and Peace" in "Introduction to Security Studies", Centre for European and North Atlantic Affairs (CENAA), Bratislava, Slovakia, 2014.

- Beraia E. "The U.S. Foreign Policy Priorities in the Post-Cold War Period (1990-2016): Georgia's Case from Transnational Challenges (Including Migration) towards Enhancing Institutional Transformation", Ph.D. thesis at International Black Sea University (IBSU), American Studies Program, Tbilisi, Georgia, 21 September, 2017.

- Buzan B., Waever O. and De Wilde J. "Security, A New Framework for Analysis", Lynne Reinner Publishers, London, 1998.

- Chifu I., Sauliuc A., Nedea B., "Energy Security Strategies in the Wider Black Sea Region", Editura Curtea Veche, Bucharest, 2010.

- Danyk Y., Maliarchuk T., Briggs C., "Hybrid War: High-tech, Information and Cyber Conflicts" in "Connections" The Quarterly Journal, Partnership for Peace Consortium of Defense Academies and Security Studies Institutes, Vol.16, no.2, Germany, Spring 2017.

- Hoffmann F.G., "Conflict in the 21st Century: The Rise of Hybrid Wars", Potomac Institute for Policy Studies, Arlington USA, 2007.

- Kaplan R.D., "The Revenge of Geography", Random House Trade Paperbacks, New York, 2013.

- Maisaia V., "The Caucasus-Caspian Regional and Energy Security Agendas - Past, Contemporary and Future Geopolitics: View from Georgia", second edition, IREX, Brussels, 2007.

- Maisaia V., Beselia M., "Asymmetrical Warfare Strategy and Its Implications to the Black Sea Regional Security in $21^{\text {st }}$ Century: Non-State Aggressive Actors and Terrorism" in "Ante Portas - Security Studies" \#2(15), Poland, 2020.

- Minix D., Hawley S., "Global Politics", Wadsworth Publishing Company, New York, 1998.

- O Tuathail G., "Critical Geopolitics: The Politics of Writing Global Space", Routledge Publishing House, London, 1996. 